\title{
CYTOLOGIC PECULIARITIES OF DIFFERENT FORMS OF ALLERGIC RHINITIS IN CHILDREN
}

\author{
I. A. Zhylenko, S. N. Nedel's'ka \\ Zaporizhzhya State Medical University
}

Abstract. Allergic rhinitis is a chronic immune disease of upper respiratory tract that still occupies the leading place among allergic disorders in children and deteriorates quality of life and physical development with further social and physiological maladaptation. Rhinocytological examination gives an opportunity to improve diagnostics, define severity of disease and degree of nasal mucus affection. Authors performed the cytological examination in 63 children with persistent (1-st group) and intermittent (2-nd group) allergic rhinitis. In all children with allergic rhinitis epithelial dysplasia or metaplasia with significant damage of squamous and cylindrical multi-row epithelium, presence of detritus have been revealed. High level of microbial contamination of nasal mucus has been registered, predominantly in children with persistent form. In both groups eosinophil cytosis was high, eosinophil-neutrophil ratio was 0,152 in 1-st group and 0,334 in 2 -nd group while normal index is lower than 0,1 . Authors claim that presence of cytological differences between the forms of allergic rhinitis and possibility to define microbial biofilms make rhinocytological examination obligatory for children with allergic rhinitis to improve quality of patients' management.

Key words: allergic rhinitis, persistent allergic rhinitis, intermittent allergic rhinitis, nasal cytology.

I. A. Zhylenko

Assistant at Department of Faculty Pediatrics in ZSMU Zaporizhzhya, 69093, Degtyaryova STR. 5-A, Apt 108,

e-mail: irina.zhilenko@gmail.com

Asthma and Allergy, 2020, 1, P. 22-27.

\section{ЦИТОЛОГІЧНІ ОСОБЛИВОСТІ ПРИ РІЗНИХ ФОРМАХ АЛЕРГІЧНОГО РИНІТУ У ДІТЕЙ}

\section{II. О. Жиленко, С. М. Недельська}

Резюме. Алергічний риніт - хронічне імунне захворювання верхніх дихальних шляхів, яке залишається на лідируючих позиціях серед алергічних захворювань у дітей і значною мірою погіршує якість життя, фізичний розвиток, що призводить до соціальної і фізіологічної дезадаптації. Проведення риноцитологічного обстеження дитини дозволяє покращити діагностику, встановити тяжкість захворювання і ступінь ураження слизової оболонки носа. Авторами виконано дослідження цитологічної картини у 63 дітей при персистуючому (1 група спостереження) і інтермітуючому (2 група) алергічному риніті. У всіх пацієнтів виявлено дисплазію або метаплазію епітелію, значні пошкодження як плаского, так і циліндричного багаторядного епітелію, наявність детриту. Було зареєстроване значне мікробне обсіменіння слизової носа у всіх дітей з алергічним ринітом, але переважно при персистуючому алергічному риніті. В обох групах еозинофільний цитоз був надмірним, еозинофільно-нейтрофільний індекс складав 0,152 в групі 1 і 0,334 в групі спостереження 2, коли норма його менше 0,1. Наявність цитологічних відмінностей, можливість виявлення мікробних біоплівок, на думку авторів, ставить метод риноцитологічного моніторингу в ряд обов'язкових досліджень у дітей з алергічним ринітом для покращення якості їх лікування.

Ключові слова: алергічний риніт, персистуючий алергічний риніт, інтермітуючий алергічний риніт, цитологічні назальні дослідження.

I. О. Жиленко Асистент кафедри факультетської педіатрії̈ ЗДМУ Запоріжжя, 69093, вул. Дегтярьова, буд 5-А, кв. 108, e-mail:irina.zhilenko@gmail.com

(c) Zhylenko I. A., Nedel's'ka S. N., 2020

«Астма та алергія», 2020, № 1, С. 22-27. 


\title{
ЦИТОЛОГИЧЕСКИЕ ОСОБЕННОСТИ ПРИ РАЗЛИЧНЫХ ФОРМАХ АЛЛЕРГИЧЕСКОГО РИНИТА У ДЕТЕЙ
}

\author{
И. А. Жиленко, С. Н. Недельская
}

\begin{abstract}
Резюме. Аллергический ринит - хроническое иммунное заболевание верхних дыхательных путей, которое занимает лидирующие позиции среди аллергических заболеваний у детей и в значительной степени ухудшает качество жизни, физическое развитие, что приводит к социальной и физиологической дезадаптации. Проведение риноцитологического обследования ребенка позволяет улучшить диагностику, установить тяжесть заболевания, степень поражения слизистой носа. Авторами выполнено исследование цитологической картины при персистирующем (1-я группа наблюдения) и при интермиттирующем (2-я группа) аллергическом рините у 63 пациентов. У всех детей с аллергическим ринитом выявлена дисплазия или метаплазия эпителия, значительное повреждение как плоского, так и цилиндрического многорядного эпителия, наличие детрита. Было зарегистрировано значительное микробное обсеменение слизистой носа у детей с аллергическим ринитом, преимущественно при персистирующем его варианте. В обеих группах эозинофильный цитоз был повышенным, эозинофильно-нейтрофильный индекс составил 0,152 в группе 1 и 0,334 в группе наблюдения 2 при норме его менее 0,1. Наличие цитологических различий, возможность выявления микробных биопленок, по мнению авторов, ставит метод риноцитологического мониторинга в ряд обязательных исследований у детей с аллергическим ринитом для улучшения качества их лечения.
\end{abstract}

Ключевые слова: аллергический ринит, персистирующий аллергический ринит, интермиттирущий аллергический ринит, цитологические назальные исследования.

И. А. Жиленко

Ассистент кафедры факультетской педиатрии ЗГМУ Запорожье, 69093, ул. Дегтярева, д. 5-а, кв.108, e-mail: irina.zhilenko@gmail.com

«Астма и аллергия», 2020, № 1, С. 22-27.

Allergic rhinitis (AR) is a chronic immune disease of upper respiratory tract and still occupies the leading place among allergic disorders in children as well as in adults. Allergic rhinitis burdens life quality, provides negative influence on child physical development, worsens study capacity, produces social and physiologic maladaptation, vascular-vegetative dystonia and causes appearance of adenoid face. Children with AR frequently get infectious and hypoxic complications like cerebrovascular and respiratory disorders $[2,5,14]$.

Study of upper respiratory tract biocenosis using high technologies allows to understand the ways of microflora persistency (bacteria, fungi etc.) due to revealed capacity of it to produce biofilms. Biofilms are the superficial agglomerates of microorganisms diving in polymeric extracellular polysaccharide matrix that was produced by these microbe associations. This capacity to produce biofilms depends on different events like quantity and quality of microorganisms, obstructive disorders in respiratory tract with edema, hypoxia, chronic inflammatory tissue damaging etc. [5, $6,8,10,11]$. Gellardi M. et al [9] by their experimental studies proved the correlation between biofilm formation and cytological type of inflammation. These scientists found out direct correlation between the grade of nasal obstruction and persistent bacteria in biofilms. These types of microbes are so-called hospital strains Pseudomonas, St. aureus, Haemophilus etc. [6, 7]. Previous works of scientists showed the necessity of cytological examination in children with chronic rhinosinusitis of allergic or non-allergic origin because it's non-invasive and simple in fulfillment and gives solid verification of diagnosis, possibility to control efficacy of therapy $[6,7,9,14]$. The document on diagnosis and AR managing ARIA (Allergic Rhinitis and its impact on Asthma) has been elaborated in 2001 and all further guidelines revisions can't propose quite definite protocols of treatment in different types of $A R$ [11]. More problems with treatment choice concern the cases of non-allergic rhinitis (NAR). Several forms of NAR have been defined: NARNE - NAR with neutrophils; NARES - NAR with eosinophils; NARMA NAR with mast cells; NARESMA - NAR with eosinophils and mast cells and overlap rhinitis - combination of AR features and NAR. These forms of rhinitis are continuously studied by famous specialists $[9,14]$. But undeniable are the results of infection complications that take place in all types of chronic rhinitis formation of biofilms, resistance to therapeutic eradication that is dependent on the type of rhinitis. So taking into consideration all these statements rhinocytological examination looks like rational implementation for patients with chronic rhinitis or rhinosinusitis $[5,8,10,14]$.

The aim of our scientific work was nasal cytology comparison in persistent AR (PAR) and intermittent AR (IAR): study of microbial contamination in children with different AR forms. 


\section{Materials and methods}

63 children of 6-15 years old with AR formed the main group of observation. The diagnosis of AR was verified according to the ARIA document recommendations. PAR was diagnosed in 33 children (the 1-st subgroup) with the main sensitization to domestic dust mites; in 30 children (the 2-nd subgroup) IAR with sensitization to pollens was confirmed. The group of 30 healthy children was examined as a group of comparison. All children were randomized by gender and age ( $\mathrm{p}$ $<0.05$ ). All patients underwent thorough study of medical history, inheritance, AR symptoms score, examining by otolaryngologists, X-ray, study of allergic sensitization by skin prick tests or RAST.

Material for cytological examining was taken early in the morning in fasting condition before the toilet of nose and throat. We use glass shovels to evacuate secret and cells from the middle portion of inferior nasal meatus performing very gentle scraping from walls. The obtained material was placed on a glass slide fixed by air for 10-15 $\mathrm{min}$ at room temperature and later by Nikiforov fluid and stained by Romanovsky-Giemsa method. The slides were observed by binocular light microscope with magnification of x 900 under immersion. Cytologic diagnostics was performed according to the recommendations of IA Kassirsky (1997), AM Melnik (1983) and MA Bazarnova (1991) [1, 2, 4]. We've found squamous and cylindrical epithelium in slides. According Melnik AM and Menshikova MM recommendations differentiation of epithelium dysplasia type and grade was performed by such criteria:

- mild grade (absence of atypical signs) - vacuole, fatty nuclear dystrophy without signs of cell rejuvenation; - moderate grade - dystrophy signs combined with mild increase of nucleo-cytoplasmic ratio;

- severe grade - anaplasia with signs of atypia.
Metaplasia was diagnosed in cases of cell transformation into another related tissue types. Epithelium degenerative changes were fixed in the case of nucleus and cytoplasmic vacuolization. Cell hyperplasia (proliferation) has been regarded as mild form of dysplasia and usually it was accompanied by high quantity of normal desquamated epithelium. Intracellular hyperplasia i.e. hypertrophy, has been defined as moderate grade of dysplasia in the case of nucleus and cytoplasm enlargement with preserved nucleus- cytoplasmic ratio $[1,2]$.

We've evaluated background in slides: mucus, detritus or fibrin fibers as indirect index of inflammatory reaction in nasal cavity. The quantity of microbes; cocci, bacilli, diplococci, tetracocci or fungi was displayed by semi-quantitative methods as mild, moderate or total contamination.

All data was analyzed by statistic software Microsoft Office 10 with $\mathrm{P}$ value $<0.05$ being considered significant for all tests. We used Bonferroni correction (2008).

Cytologic data of patients are reflected in table 1.

According to table 1 mucus was present at all slides without any difference in healthy or children with AR. Detritus was present reliably more frequent $(\mathrm{p}<0.0001)$ in children with AR in both subgroups without significant difference in PAR or IAR ( $p>0.05)$. Squamous epithelium was present at slides of all observed children. For healthy patients it was singular and in AR it was situated by groups, clusters or even layers without statistic difference. Signs of epithelium dysplasia of the 1-st and 2-nd grade were found in both subgroups. Metaplasia and proliferation reliably $(\mathrm{p}<0.05)$ frequent in children with AR in both subgroups without statistic difference in PAR or IAR. This data testifies presence of structural restructuring of epithelium in AR under the influence of allergic inflammation independently of AR type that completely coincide to referent data $[4,7,8]$. Multirow

Ta b l e 1. Frequency of cytological findings in rhinocytograms of children with AR and healthy ones

\begin{tabular}{l|c|c|c|c}
\hline \multicolumn{1}{c|}{ Indicators } & $\begin{array}{c}\text { Subgroup } 1 \\
(\mathrm{n}=33)\end{array}$ & $\begin{array}{c}\text { Subgroup } \\
(\mathrm{n}=30)\end{array}$ & $\begin{array}{c}\text { Healthy } \\
(\mathrm{n}=30)\end{array}$ & $\mathrm{P}$ \\
\hline Detritus & $27(81,8)$ & $19(63,3)$ & $8(26,7)$ & $\mathrm{P}_{1}<0,0001 ; \mathrm{P}_{2}<0,01 ; \mathrm{P}_{1 / 2}>0,05$ \\
\hline Squamous epithelium & $31(93,9)$ & $29(96,6)$ & $30(100)$ & $\mathrm{P}_{1}>0,05 ; \mathrm{P}_{2}>0,05 ; \mathrm{P}_{1 / 2}>0,05$ \\
\hline--- -singular & $17(51,5)$ & $19(63,3)$ & $24(80)$ & $\mathrm{P}_{1}<0,05 ; \mathrm{P}_{2}>0,05 \mathrm{P}_{1 / 2}>0,05$ \\
\hline-- -clusters & $3(9)$ & $2(6,6)$ & $4(13,3)$ & $\mathrm{P}_{1}>0,05 ; \mathrm{P}_{2}>0,05 ; \mathrm{P}_{1 / 2}>0,05$ \\
\hline-- -groups & $8(24,2)$ & $7(23,3)$ & $2(6,6)$ & $\mathrm{P}_{1}<0,05 ; \mathrm{P}_{2}>0,05 ; \mathrm{P}_{1 / 2}<0,05$ \\
\hline ---layers & $7(21,2)$ & $7(23,3)$ & $2(6,6)$ & $\mathrm{P}_{1}>0,05 ; \mathrm{P}_{2}>0,05 ; \mathrm{P}_{1 / 2}>0,05$ \\
\hline Cylindrical epithelium & $3(9)$ & $4(13,3)$ & $2(6,6)$ & $\mathrm{P}_{1}>0,05 ; \mathrm{P}_{2}>0,05 ; \mathrm{P}_{1 / 2}>0,05$ \\
\hline Degenerative epithelium & $11(33)$ & $7(23,3)$ & $3(10)$ & $\mathrm{P}_{1}<0,05 ; \mathrm{P}_{2}>0,05 ; \mathrm{P}_{1 / 2}>0,05$ \\
\hline Dysplasia & $19(57,5)$ & $16(53,3)$ & $3(10)$ & $\mathrm{P}_{1}<0,05 ; \mathrm{P}_{2}<0,05 ; \mathrm{P}_{1 / 2}>0,05$ \\
\hline Proliferation & $11(33)$ & $8(26,6)$ & $2(6,6)$ & $\mathrm{P}_{1}<0,05 ; \mathrm{P}_{2}>0,05 ; \mathrm{P}_{1 / 2}>0,05$ \\
\hline Hyperplasia & $6(18,1)$ & $5(16,6)$ & $4(13,3)$ & $\mathrm{P}_{1}>0,05 ; \mathrm{P}_{2}>0,05 \mathrm{P}_{3}>0,05 ; \mathrm{P}_{1 / 2}>0,05$ \\
\hline Metaplasia & $9(27,2)$ & $6(20)$ & $1(3,3)$ & $\mathrm{P}_{1}<0,05 ; \mathrm{P}_{2}>0,05 \mathrm{P}_{1 / 2}>0,05$ \\
\hline Microflora & $18(54,5)$ & $14(46,6)$ & $8(26,7)$ & $\mathrm{P}_{1}<0,05 ; \mathrm{P}_{2}<0,05 ; \mathrm{P}_{1 / 2}<0,05$ \\
\hline Cocci & $18(54,5)$ & $14(46,6)$ & $8(26,7)$ & $\mathrm{P}_{1}<0,05 ; \mathrm{P}_{2}>0,05 ; \mathrm{P}_{1 / 2}>0,05$ \\
\hline Bacillus & $8(24,2)$ & $9(30)$ & $4(13,3)$ & $\mathrm{P}_{1}>0,05 ; \mathrm{P}_{2}>0,05 ; \mathrm{P}_{3}>0,05 ; \mathrm{P}_{1 / 2}>0,05$ \\
\hline Diplococci & $5(15,1)$ & $3(10)$ & $5(16,6)$ & $\mathrm{P}_{1}>0,05 ; \mathrm{P}_{2}>0,05 ; \mathrm{P}_{1 / 2}>0,05$ \\
\hline Mixture of microbes & $19(27,2)$ & $5(16,6)$ & $6(20)$ & $\mathrm{P}_{1}<0,05 ; \mathrm{P}_{2}>0,05 ; \mathrm{P}_{1 / 2}<0,05$ \\
\hline
\end{tabular}


Ta b l e 2. Comparative characteristics of cell presentation in rhinocytograms of children with different types of AR and healthy children

\begin{tabular}{l|c|c|c|c}
\hline \multicolumn{1}{|c|}{ Observed groups } & $\begin{array}{c}\text { Neutrophils } \\
(\%)\end{array}$ & $\begin{array}{c}\text { Eosinophils } \\
(\%)\end{array}$ & $\begin{array}{c}\text { Monocytes } \\
(\%)\end{array}$ & $\begin{array}{c}\text { Lymphocytes } \\
(\%)\end{array}$ \\
\hline Subgroup1 & $63,94 \pm 25,89$ & $9,75 \pm 17,24$ & $2,81 \pm 1,68$ & $8,29 \pm 6,3$ \\
\hline Subgroup 2 & $62,85 \pm 26,3$ & $21,05 \pm 27,24$ & $5,11 \pm 3,56$ & $7,41 \pm 5,6$ \\
\hline Healthy children & $71,93 \pm 25,56$ & $2 \pm 0,81$ & $2,3 \pm 1,75$ & $5,48 \pm 6,85$ \\
\hline Value P & $\mathrm{P}_{1}>0,05 ; \mathrm{P}_{2}>0,05 ; \mathrm{P}_{1 / 2}>0,05$ & $\mathrm{P}_{1}<0,05 ; \mathrm{P}_{2}<0,05 ; \mathrm{P}_{1 / 2}>0,05$ & $\mathrm{P}_{1}>0,05 ; \mathrm{P}_{2}<0,05 ; \mathrm{P}_{1 / 2}>0,05$ & $\mathrm{P}_{1}>0,05 ; \mathrm{P}_{1 / 2}>0,05$ \\
\hline
\end{tabular}

ciliated epithelium at slides was represented by cylindrical cells. They were also affected and dystrophy of nucleus, cytoplasm and damaged ciliated apparatus was noticed but significant statistic changes in groups were absent ( $\mathrm{p}>0.05)$.

In the slides of the 1-st subgroup microbial contamination was reliably more frequent $(\mathrm{p}<0.05)$. Differences for bacilli, diplococci, tetracocci contamination were absent. Concerning the mixture of strains it was statistically predominant in the slides of patients with PAR.

From the table 2 we can see that content of neutrophils and lymphocytes was also comparable to the quantity of these cells in healthy children $(p>0.05)$. Relative quantity of eosinophils in slides of the 1-st and 2-nd subgroups was reliably higher than in healthy children $(\mathrm{p}<0.05)$. Difference of eosinophils in PAR and IAR was non-significant $(\mathrm{p}>0.05)$ These data testify presence of allergic inflammation in both subgroups of AR, that coincide with results of another researchers $[7,8$, $13,14]$.

We used eosinophil to neutrophil ratio recommended by Shinogi that is much more informative for allergic inflammation defining. In normal condition index must be lower than $0,1[16]$. We've implemented it and found out that in children with PAR it was 0.152 , in children with IAR - 0.334, in healthy ones - 0.027. Index was really higher in AR but twice more in IAR than in PAR.

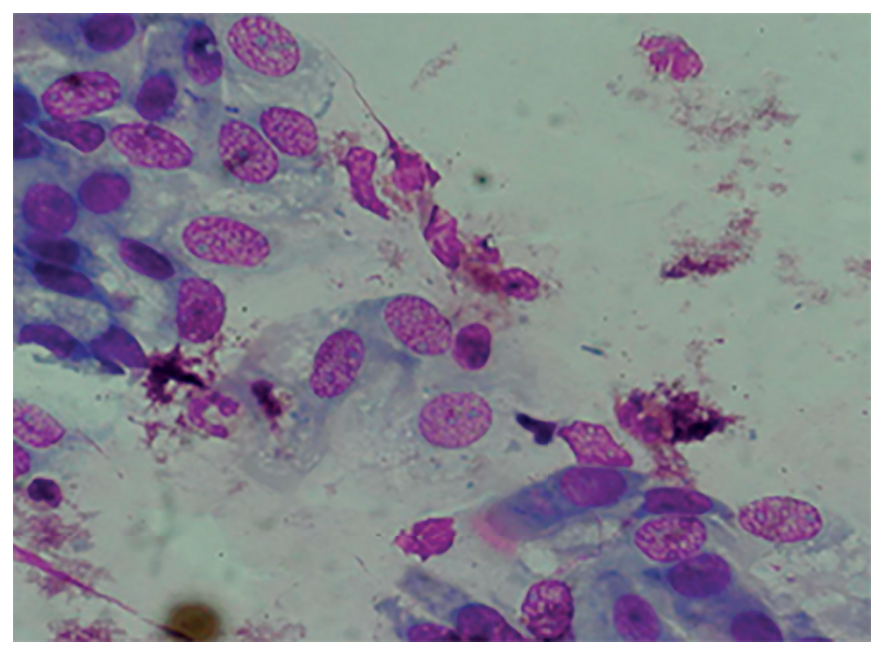

Picture 1. Epithelium in children with AR. Romanovski-Giemsa staining, magnification x 900 .
This fact can be explained by different effectors of inflammation in different types of AR dependently on allergen type or additional influence of microbes. Relative monocyte quantity in smears was reliably higher in 2-nd subgroup than in healthy children $(\mathrm{p}<0.05)$. In the 1-st subgroup such difference in monocyte content wasn't found.

Thus in children with AR we've found mucus and detritus in rhinocytological slides. In the group of healthy children epithelium is singular or visualized by groups and in AR epithelium abruption is significant and it is present as accumulations or stratum of cells. In AR epithelium presentation more frequently has signs of metaplasia, degenerative-distrophic changes of the squamous and cylindrical epithelium. During acute period of AR the quantity of eosinophils and monocytes is increased in AR patients and it's higher in IAR than in PAR. Our study doesn't reveal statistic difference of eosinophil count in PAR and IAR that can be explained by quantity of groups. Sensitivity of $\mathrm{P}$ value in such quantity of examined children is $48 \%$. To confirm the statistic reliability of $\mathrm{P}$ value with sensitivity $95 \%$ in the same tendencies of cell distribution studied groups has to be 120 and 110 respectively. Indirect confirmation of this prevalence was shown by eosinophil-neutrophil ratio that was higher than normal index and twice higher in children with IAR than in PAR. Taking into regard the predominance of microbial contamination in

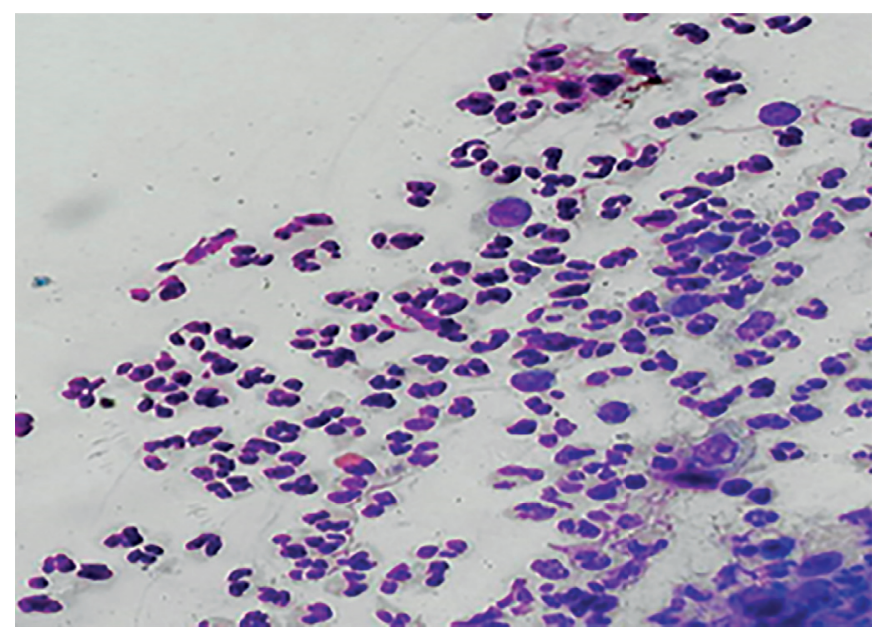

Picture 2. Rhinocytogramm of patient with PAR. RomanovskiGiemsa staining, magnification x 900 . 


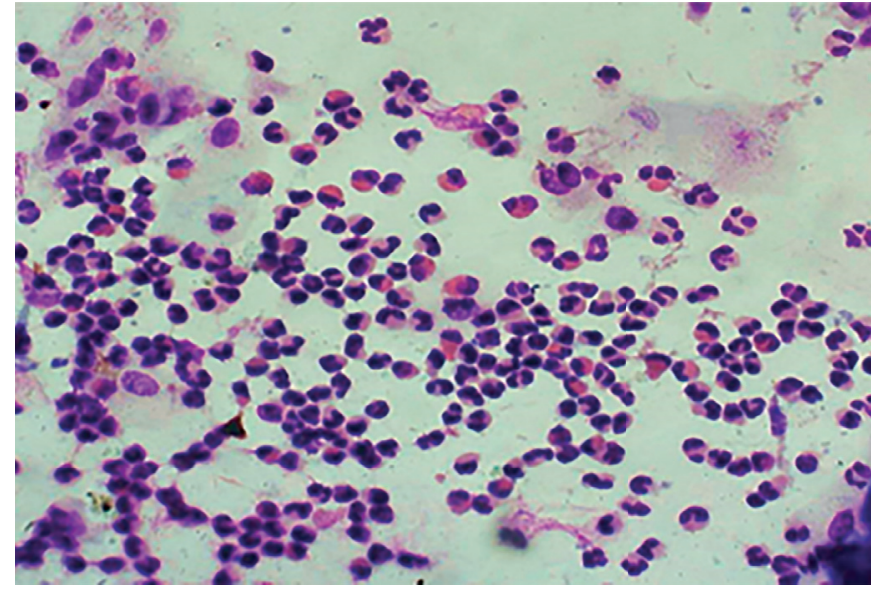

Picture 3. Rhinocytogramm of patient with IAR. RomanovskiGiemsa staining, magnification $x 900$.

PAR we can assume additional influence of it due to the higher neutrophil influx than eosinophil one.

\section{Conclusoins}

We can make such conclusions: PAR and IAR has common features of inflammatory process accompanied

\section{REFERENCE}

1. Bazarnova MA, Vorobjov AI, Barkagan ZS, et al. Rukovodstvo po klinicheskoy laboratornoy diagnostike (Clinical laboratory diagnostics guide). Kiyiv: Zdorovja; 1983. 240 s.

2. Kassirskij IA, Aleksejev GA. Klinicheskaya gematologija (Clinical hematology). Moskwa: Med. Lit-ra; 1997. $811 \mathrm{s.}$

3. Lopatin AS, Guschin IS, Yemel'yanov AV, et al. Klinicheskiye rekomendacii po diagnostike I lecheniyu allergicheskogo rinita (Clinical recommendations for the diagnosis and treatment of allergic rhinitis). Consilium-Medicum. 2001;9(3):1-19.

4. Menshikova VV. Klinicheskaya laboratornaya analitika (Clinical laboratory analytics). Moskva: Labinform-RAMLD; 1999. $234 \mathrm{s.}$

5. Fayans AA, Yershova VP, Akimova TV. Kolichestvenniye kriterii rinocitogrammy zdorovogo cheloveka (Quantitative criteria for the rhinocytogram of a healthy person). Klinicheskaya i laboratornaya diagnostika. 1996;2:13-14.

6. Cohen M, Kofonow J, Nayak JV, et al. Biofilms in chronic rhinosinusitis: a review. Am J Rhinol Allergy. 2009;23:255-60. DOI:10.2500/ ajra.2009.23.3319.

7. Gellardi M, Incorvaia C, Fiorelli ML, et al. The clinical stage of allergic rhinitis is correlated to Inflammation detected by nasal cytology. Inflam \& Allergy-Drug Targets. 2011;10(6):1-5. DOI: 10.2174 /187152811798104917.

8. Gellardi M, Incorvaia C, Passalacqua G, et al. The classification of allergic rhinitis and its cytological correlate. Allergy. 2011;66:1624-5. DOI:10.1111/j.1398-9995.2011.02741.x.

9. Gellardi M, Passalacqua G, Fiorella ML, et al. Assessment of biofilm by nasal cytology in different forms of rhinitis and its functional correlation. Eur Ann Allergy Clin Immunol. 2013;45(1):25-29.

10. Gelardi M, Iannuzzi L, Tafuri S, Passalacqua G, Quaranta N. Allergic and non-allergic rhinitis: relationship with nasal polyposis, asthma and family history. Acta Otorhinolaryngol Ital. 2014;34(1):36-41.

11. Hoshtim CJ, Choi JY, Lowe D, et al. Biofilm detection with hemotoxylineosin staining. Arch Otolaryngol Head Neck Surg. 2010:136:453-6. DOI: 10.1001/archoto.2010.62.

12. Jan L Brothet, Jean Bousquet, et al. Allergic Rhinitis and its Impact on Asthma (ARIA) guidelines-2016 revision. J Allergy Clin Immunol. 2017;140(4):1-9. DOI :10.1016〉j.jaci.2017.03.050.

13. Jean R, Delacourt C, Rufin P, et al. Nasal cytology in rhinitis children, comparison between brushing and blowing the nose. Allergy. 1996;15(12):932-934. DOI:10.1111/j.1398-9995.1996.tb04496.x. by affection of mucus membrane with different grade of dysplasia and further metaplasia (rebuilding of epithelium) that is dependent on duration and severity of disease. These forms of AR have cytological differences: in IAR eosinophil infiltration is predominant and accompanied by quite peculiar clinics. In cytological presentation of PAR neutrophil cytosis will be predominant and it also define peculiar clinic features like persistent course, accompanied by serious obstruction and it induce so called vicious circle -combination of allergic and infectious inflammation cause remodeling of mucus membranes with chronic nasal obstruction and these changes promote formation of biofilm resistant for eradication $[6,9]$.

Cytological examination gives additional information helpful to clarify inflammatory peculiarities in children with AR, severity of mucus affection, presence of microbial conglomerates, biofilms. Such information is very significant for caregivers to choose proper medications - antibiotics and glucocorticoids, antihistamines, specific immune therapy. Taking into account the fact that glucocorticoids beside the anti-inflammatory influence provide immunosuppressive effect necessity of cytological monitoring become obligatory in management of AR patients.

\section{ЛІТЕРАТУРА}

1. Базарнова МА, Воробьев АИ, Баркаган 3С, и др. Руководство по клинической лабораторной диагностике. Київ: Здоров'я; 1983. 240 с.

2. Кассирский ИА, Алексеев ГА. Клиническая гематология. Москва: Мед. лит-ра; 1997. 811 с.

3. Лопатин АС, Гущин ИС, Емельянов АВ, и др. Клинические рекомендации по диагностике и лечению аллергического ринита. ConsiliumMedicum. 2001;9(3):1-19.

4. Меньшикова ВВ. Клиническая лабораторная аналитика. Москва: Лабинформ-РАМЛД; 1999. 234 с.

5. Фаянс АА, Ершова ВП, Акимова ТВ. Количественные критерии риноцитограммы здорового человека. Клиническая и лабораторная диагностика. 1996;2:13-14.

6. Cohen M, Kofonow J, Nayak JV, et al. Biofilms in chronic rhinosinusitis: a review. Am J Rhinol Allergy. 2009;23:255-60. DOI:10.2500/ ajra.2009.23.3319.

7. Gellardi M, Incorvaia C, Fiorelli ML, et al. The clinical stage of allergic rhinitis is correlated to Inflammation detected by nasal cytology. Inflam \& Allergy-Drug Targets. 2011;10(6):1-5. DOI: 10.2174 /187152811798104917.

8. Gellardi M, Incorvaia C, Passalacqua G, et al. The classification of allergic rhinitis and its cytological correlate. Allergy. 2011;66:1624-5. DOI:10.1111/j.1398-9995.2011.02741.x.

9. Gellardi M, Passalacqua G, Fiorella ML, et al. Assessment of biofilm by nasal cytology in different forms of rhinitis and its functional correlation. Eur Ann Allergy Clin Immunol. 2013;45(1):25-29.

10. Gelardi M, Iannuzzi L, Tafuri S, Passalacqua G, Quaranta N. Allergic and non-allergic rhinitis: relationship with nasal polyposis, asthma and family history. Acta Otorhinolaryngol Ital. 2014;34(1):36-41.

11. Hoshtim CJ, Choi JY, Lowe D, et al. Biofilm detection with hemotoxylineosin staining. Arch Otolaryngol Head Neck Surg. 2010:136:453-6. DOI: 10.1001/archoto.2010.62.

12. Jan L Brothet, Jean Bousquet, et al. Allergic Rhinitis and its Impact on Asthma (ARIA) guidelines-2016 revision. J Allergy Clin Immunol. 2017;140(4):1-9. DOI :10.1016〉j.jaci.2017.03.050.

13. Jean R, Delacourt C, Rufin P, et al. Nasal cytology in rhinitis children, comparison between brushing and blowing the nose. Allergy. 1996;15(12):932-934. DOI:10.1111/j.1398-9995.1996.tb04496.x.

14. Jirapongsanuruk O, Vichyanond P. Nasal cytology in the diagnosis of allergic rhinitis in children. Allergy Asthma Immunology. 1998;80(2):165170.

15. Prorero MC, Macchi A, Antognazza S, et al. Allergic and non-allergic 
14. Jirapongsanuruk $\mathrm{O}$, Vichyanond $\mathrm{P}$. Nasal cytology in the diagnosis of allergic rhinitis in children. Allergy Asthma Immunology. 1998;80(2):165170.

15. Prorero MC, Macchi A, Antognazza S, et al. Allergic and non-allergic rhinitis in children. The role of nasal cytology. Open Journal of Pediatrics. 2013;3:133-138. DOI: 10.4236/ojped.2013.32024.

16. Shinogi J, Majima Y, Takeuchi K, et al. Quantitative cytology of nasal secretions with perennial allergic rhinitis in children: comparison of noninfected and infected conditions. Laryngoscope. 1998;208(5):703705. DOI: $10.1097 / 00005537-199805000-00014$ rhinitis in children. The role of nasal cytology. Open Journal of Pediatrics. 2013;3:133-138. DOI: 10.4236/ojped.2013.32024.

16. Shinogi J, Majima Y, Takeuchi K, et al. Quantitative cytology of nasal secretions with perennial allergic rhinitis in children: comparison of noninfected and infected conditions. Laryngoscope. 1998;208(5):703705. DOI: 10.1097/00005537-199805000-00014.
Надійшла до редакції 15.12 .2019 p.

Прийнято до друку: 04.02.2020 p.
I. A. Zhylenko,

ORCID ID

https://orcid.org/0000-0003-0986-0587

S. N. Nedel's'ka

ORCID ID

https://orcid.org/0000-0003-2277-3875 